\title{
Britain Arms Trade in The Middle East During the Arab Israeli Wars of 1967 and 1973: A Comparative Historical Review
}

\section{Muhamad Hasrul Zakariah}

To Link this Article: http://dx.doi.org/10.6007/IJARBSS/v10-i11/8050

DOI:10.6007/IJARBSS/v10-i11/8050

Received: 09 September 2020, Revised: 12 October 2020, Accepted: 06 November 2020

Published Online: 26 November 2020

In-Text Citation: (Zakariah, 2020)

To Cite this Article: Zakariah, M. H. (2020). Britain Arms Trade in The Middle East During the Arab Israeli Wars of 1967 and 1973: A Comparative Historical Review. International Journal of Academic Research in Business and Social Sciences, 10(11), 745-755.

\section{Copyright: (c) 2020 The Author(s)}

Published by Human Resource Management Academic Research Society (www.hrmars.com)

This article is published under the Creative Commons Attribution (CC BY 4.0) license. Anyone may reproduce, distribute, translate and create derivative works of this article (for both commercial and non-commercial purposes), subject to full attribution to the original publication and authors. The full terms of this license may be seen at: http://creativecommons.org/licences/by/4.0/legalcode

Vol. 10, No. 11, 2020, Pg. 745 - 755

Full Terms \& Conditions of access and use can be found at http://hrmars.com/index.php/pages/detail/publication-ethics 


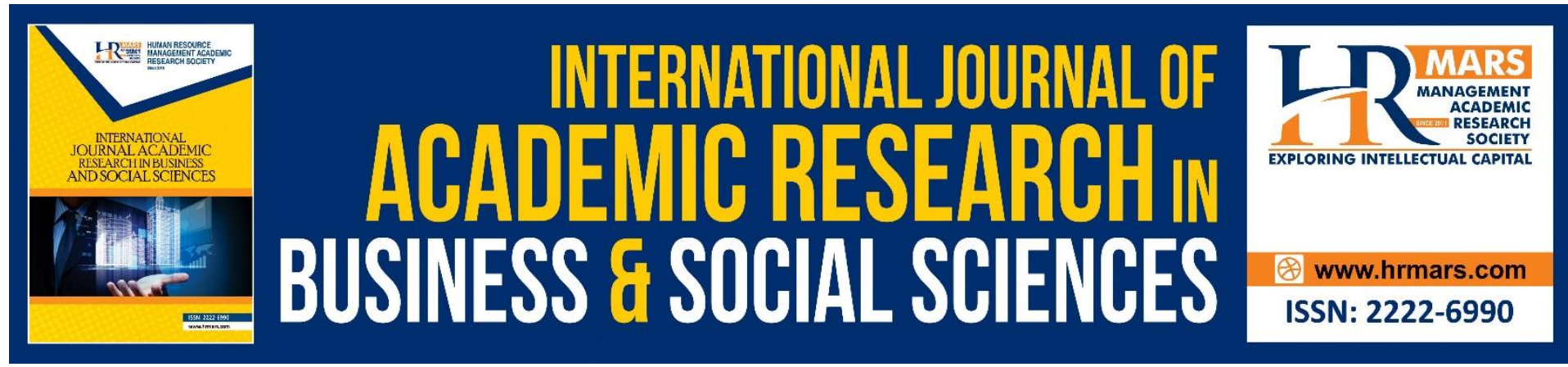

\title{
Britain Arms Trade in The Middle East During the Arab Israeli Wars of 1967 and 1973: A Comparative Historical Review
}

\author{
Muhamad Hasrul Zakariah \\ History Section, School of Humanities, Universiti Sains Malaysia, 11800 Penang, Malaysia \\ Email: rasul_hasrul02@yahoo.com
}

\begin{abstract}
This article examines the policy of the British government towards the arm trade activity in the Middle East during the 1967 and 1973 Arab Israeli Wars. The purpose of the study is to compare the justification and approaches taken by London on the issue of arm exports to the conflicting nations between the Sixth Days of War in 1967 and the 1973's Yom Kippur War. From historical perspective, this study argues that despite the changes of the government from Labor to the Conservative in 1970, the arms sale policy was remained unaltered. The reason of the unchanged policy was based on the economic assessment that the region was one of the most lucrative market for Britain's arm sales. In addition to the effort of safeguarding Britain's oil import and other businesses, the arms trade has emerged as one of the vital factors which dominated London consideration in constructing her foreign affairs strategy in the Middle East during the conflicts. The evidences and data extracted mostly from the government archival records declassified in London, proven the argument that the British policy towards the two wars was enduring and very much influenced by the profitable arm trade consideration.
\end{abstract}

Keywords: Arab-Israeli Wars, Britain, Arms, Trade, Middle East.

\section{Introduction}

On June 1967, a bloody war broke out between the Arabs coalition and the Israelis in the Middle East. Although the war lasted only for sixth days but the impact of the crisis such as the increasing numbers of Palestinian refugees and the occupation of East Jerusalem remained unresolved until today. The Israelis won the battle and occupied the Arab territories such as the Golan Height from Syria, the West Bank of Jordan and the Egypt's land of Sinai. Eventually the war ended with the armistice agreement and finalized with the enforcement of the UN Resolution 242. Unfortunately, the peace agreement was not lasted longer when another war blasted on October 1973. The outbreak known as The Yom Kippur War witnessed the loss of the Arab to the Israelis again. Nonetheless, this time the war paved way to the more comprehensive peace process orchestrated by the American leaders especially the US Secretary of State, Dr. Henry Kissinger. The truce process concluded with the peace agreement between Egyptian President, Anwar Sadat and his counterpart the Israelis Prime 
Minister Menachem Begin in the Camp David Accord of 1978; and subsequently the bilateral peace agreement of 1979 .

This essay is comparing the history of British military equipment trades between the two Arab Israelis wars. Based on the archival documents which recently declassified in London, the discussion will unveil the luxury arm deals of the British in the Middle East during the outbreak years. Although London was not involved directly in the battle, but her military business in the region was highly importance. Hence, the attitude of the British government towards the wars was very much influenced by the business calculation. During the conflict, London must consider wisely between the important of restoring a lasting peace to ensure the oil flow was not disrupted, and at the same time realizing that the escalating of conflict between the two traditional enemies will boost the demand of military equipment and supply. Thus, the British must balance her approach and attitude by considering both scenarios in order to preserve her vital economic interest in the region. The important question here is to what extent the outbreak has a significant links to the British arms business activity in the region; and subsequently determined London attitudes towards the momentous wars. By examining the archival documents, the essay main objective is to disclose and compare the historical facts and figures between the two wars which will prove that the wars were critically substantial to the British arm business in the Middle East region.

\section{Britain Arm Supplies during the Sixth Day Arab-Israeli War of 1967 Period}

In the period of 1950s and 1960s, Middle Eastern region especially the Arab nations emerged as one of the most important market to the British arm supplies. The escalation of military conflict between the Arabs and the Israelis during this period which finally ended with the war of 1967 augmented a demand of military equipment supplies from Britain. As predicted by London, the export of her arm supplies to the Arab world generated a huge profit, estimated around $\mathrm{f} 250$ million from three to five years during the crisis period. Based on a document entitles 'Arm Sales to Middle East' by Crosswait (1968), during the catastrophic time, among the Arab countries which purchased a huge number of arms were Saudi Arabia and Libya. These countries contributed to the enormous profit to London in arm deals with military contracts valued approximately between $£ 40$ to $£ 50$ million per year. Suffice to quote that the export to Riyadh in 1967 was very rewarding. Based on the record from the UK Foreign and Commonwealth Office, the Saudi kingdom had purchased 42 Lightening aircrafts valued at $£ 40$ million in 1967. In addition, they also purchased military radar equipment from Britain valued at $£ 23$ million and 12 Provost jets for $£ 1.8$ million. For the Libyan, they bought military equipment from Britain such as 14 Lightening aircrafts valued at $£ 18$ million, 1 frigate with a contract of $£ 6.8$ million for three years as well as subscribed the British's Air Defense Scheme for $£ 132$ million (Brown, 1967).

Regarding the business prospect, the Arab countries appeared to be the profitable market to the British arm supplies. For instance, prior to the 1967's war London estimated that the contract to supply arms and ammunition to Iraq was nearly $£ 1.76$ million (Brown, 1967). Overall, it is also worth to mention that from 1962 to 1967, the export of British arms to the Arab world was ten per cent from the total of her arm export worldwide. Cumulatively, Britain arm sales to the Middle East from 1966 to 1967 was worth more than USD\$ 775 million or 50 percent from the total of arms export to the developing countries. As a comparison, Britain arms export to American Latin was USD 328 million or 21 percent, Africa was USD\$ 219 million (14), East Asia was USD\$ 134 million (9\%) and South Asia was USD\$ 96 million or 6 percent only (ACDA, 1976). 
It is important to stress here that during the war, the demand of arms supply increased tremendously. This could be seen from the military expenses from the GDP of the conflicting nations. Based on a study by Gottheil (1974), Tel Aviv alone spent 8.2 percent of her GDP to purchase arms in 1961 and it increased to 13.8 percent in 1967 and 25.1 per cent in 1969. Whilst the Arab countries such as the UAR, Iraq, Jordan and Syria spent 38.6 percent in 1961 and the expenses increased to 46.9 percent in 1967 and 55.7 percent of their GDP in 1969. Additional statistic from the following British government's record proven the importance of the arm sales to the region prior to the 1967's war, particularly to the Arab countries.

Table 1: Value of Arm sales by UK ( $\mathrm{f}$ millions)

\begin{tabular}{|l|l|l|l|l|l|l|}
\hline Countries/Year & 1962 & 1963 & 1964 & 1965 & 1966 & 1967 \\
\hline Arabs & 3.5 & 5.4 & 8.4 & 8.5 & 11 & $\mathrm{X}$ \\
\hline Israel & 2.2 & 1.2 & 0.8 & 1.8 & 2.1 & $\mathrm{X}$ \\
\hline World & 97.5 & 112.6 & 103.7 & 101.7 & 151.5 & 163.6 \\
\hline
\end{tabular}

NOTE: X VALUE WAS STILL CALCULATED BY MID OF 1967

SOURCE: Foreign ANd Commonwealth office UK. (1967). FILE FCO 17/114, THe Working Practice of OPD (67)68 on ARM SALES to the MidDle EAST. London: the NATIONAL ARCHIVE.

It is significance to emphasize in this discussion that in the era of 1960s, the British must compete with her rival especially the Soviet Union to secure the Arab arms market. Due to the spread of Soviet influences in the region between 1950s to 1960s, the British prospect of arms export become vulnerable and insecure. In general, from 1966 to 1975 nearly seventieth per cent of the Soviet's arm export to developing countries went to the Middle East. This fact is shown in the following table 2 statistic.

Table 2: Soviet Arm Sales to Developing Regions (cumulative) between 1966-1975

\begin{tabular}{|l|c|c|}
\hline Regions & Value (USD million) & $\begin{array}{l}\text { Soviet export to developing } \\
\text { regions (\%) }\end{array}$ \\
\hline Middle East & 6,300 & 68 \\
\hline South Asia & 1,749 & 19 \\
\hline Africa & 1,086 & 12 \\
\hline Latin America & 84 & 1 \\
\hline East Asia & 15 & 0.2 \\
\hline Total & 9,234 & \\
\hline
\end{tabular}

SOURCE: ACDA, uS ARMS CONTROL AND DISARMIng AgENCY (1966). WorLd MILITARY EXPENDITURES AND Arms Transfers, 1966. Washington: US Government Printing Office. PP. 77-80

\section{Britain arm exports in the Yom Kippur War of 1973}

As a comparison, the importance of Middle East region to the British's arms business remained the same in 1973's war. From the British government records, between 1971 to 1985 the region has emerged as one of the most luxurious market for British arms supplies. The Arab states alone (excluding Iran and Israel) were accounted for 44.5 per cent of total arms import to the Third World. As stated by Deger (1986), the value of the Arab purchased through this period was worth USD\$127.26 billion. In fact, as quoted from the record by Ministry of Defense (MOD), the Middle East region was the most important market for British arms. From the record, it clearly indicated that the total export orders of the British defense equipment from 1969 to 1970 was worth $f 551$ million and the deliveries of defense 
equipment from 1967 to 1970 amounted more than $f 620$ million (MoD, 1967). In addition, based on the Customs Return Records, in 1972 alone there were more than $£ 687,000$ worth of combat aircraft sold to the Middle East and it increased to $£ 2$ million between January and August 1973.

Britain exported warships worth more than f18 million from 1972 to August 1973 to the Middle Eastern countries where the main destinations were Oman, Iran and Saudi Arabia. Another exported item during the same period was explosives, which were worth more than f2 million. During the same period there was a significant increment of the arms and ammunitions supplies worth more than $£ 23$ million. The major purchasers were Dubai, Libya, Israel, Qatar, Abu Dhabi and Kuwait (Day, 1973). The detail of the arm supplies from 1969 to September 1973 is stated in the following table 3 based on the record declassified in London by the Economic and Statistic Division, Department of Trade and Industry, UK.

Table 3: United Kingdom Export (£ million)

\begin{tabular}{|l|l|l|l|l|l|l|l|}
\hline $\begin{array}{l}\text { 1969- } \\
\text { September } \\
1973\end{array}$ & Europe & $\begin{array}{l}\text { Middle } \\
\text { East }\end{array}$ & Africa & $\begin{array}{l}\text { North } \\
\text { America }\end{array}$ & $\begin{array}{l}\text { Latin } \\
\text { America }\end{array}$ & $\begin{array}{l}\text { Rest of } \\
\text { the } \\
\text { World }\end{array}$ & Total \\
\hline Warship & - & 31 & 8 & 7 & 1 & 21 & 68 \\
\hline $\begin{array}{l}\text { Combat } \\
\text { aircraft }\end{array}$ & 5 & 36 & 2 & 39 & 3 & 5 & 90 \\
\hline $\begin{array}{l}\text { Arms and } \\
\text { ammunition }\end{array}$ & 101 & 110 & 19 & 7 & 5 & 65 & 307 \\
\hline Aircraft Engine & 291 & 44 & 21 & 311 & 16 & 72 & 755 \\
\hline $\begin{array}{l}\text { Parts of aircraft } \\
\text { (all aircraft) }\end{array}$ & 252 & 55 & 26 & 82 & 21 & 83 & 519 \\
\hline $\begin{array}{l}\text { Electronic, } \\
\text { radio and radar } \\
\text { communication }\end{array}$ & 155 & 58 & 43 & 43 & 21 & 68 & 431 \\
\hline Total & 799 & 334 & 119 & 489 & 67 & 314 & 2,122 \\
\hline
\end{tabular}

SOURCE: ECONOMIC AND StATISTIC Division, DePARTMENT OF TRADE AND INDUSTRY. (1973). EXTRACTED FROM FILE FCO 93/293, LONDON: THE NATIONAL ARCHIVE.

From the above table, it is perceivably clear that the Middle Eastern region was one of the main markets for the British export of warships, combat aircraft, arms and ammunition during the period of 1969 to 1973 . From the breakdown, more than 46 per cent of the British export of warships went to the Middle East with a total value of $£ 31$ million and 40 percent of the combat aircrafts worth $£ 36$ million was exported into the region. In fact, the Middle Eastern region was highlighted as the highest buyer of the British arms and ammunitions with a value of export of $£ 110$ million or 35 per cent of the total supplies. These figures excluded the aircraft engines, aircraft parts and electronic equipment which were mostly used for military purposes. On top of this statistic, it was also estimated that the total value of the Arab imports of major weapons from 1971 to 1975 (at constant 1985 prices) was more than USD\$22.9 billion and therefore it was very hard for Britain to let this prospect gone. (Brzoska, 1987) 


\section{British Reaction towards the Wars and the Arm Trades Consideration}

Prior to the 1967's war, the British government under Labor Prime Minister, Harold Wilson had placed arms trade regulation as one of the important agenda in his policy. Indeed, Labor had created a new post of Minister of Disarmament within the Foreign Office to regulate the armament policy. Lord Chalfont was appointed to push more on arms trade regulations. A study by Stahl (2019) described that for two years, whenever Chalfont raised the issue, he was met with extensive memoranda stating the impossibility of setting up an effective multilateral or international agreement on arms limitation. When growing tensions in the region erupted into Sixth-Day War, Chalfont made another attempt for the arm limitation. Chalfont convinced Foreign Secretary George Brown to instruct staff members to reconsider the question of arms export to the region. However, Chalfont was confronted not only with reluctant subordinates but also with the political priorities on the Labor Party, which stood in the way of more regulations, especially in the Middle East. The reaction was relied upon the fact that the British government at that time was facing the balance of payment's problem. Although the economy was in good condition, but the Labor inherited from the former regime a growing trade deficit.

For Harold Wilson, the Arab countries and Iran were keys to solving British's economic problem. Britain depended heavily on oil import from these countries which their prices were reasonably cheap and thus helped significantly Britain to reduce the balance oil trade deficit. Therefore, their interests particularly the arms supply were supported wherever possible. In a memorandum prepared for the cabinet at the request of Lord Chalfont, Foreign Office officials recognized that the arms export to Arab countries were seen by the public with a critical eye. However, since 'national interests' were concentrated in the Arab countries and Persian Gulf States, securing the 'stability of the area' would be necessary. As stated by Brown (1967), Britain was obligated to supply reasonable quantities of arms to enable [the Middle East countries]to deter external attacks and internal subversion. Although the British government controlled and limited the arm supply to the Middle East when the conflict erupted, London still did not enforce any unilateral embargo during the war as a part of their policy. This approach was based on past experiences in Iran and Iraq where revolutions had endangered the business of British oil companies. For Whitehall, the moderates in the Arab world need to acquire arms from the West if they are to avoid being drawn into a still closer relationship with the Soviet Union.

The arms export to the Middle East also contributed in a more direct way to reducing the balance of payments deficit. Because of the growing demand for oil, imports from the Middle East increased sharply in the late 1960s, with no sign that this trend would slow down. Against this backdrop, arms exports became a decisive factor in maintaining balanced trade. Britain's arm exports to the Middle East had recovered from the backlash reached the same level as that of the mid-1950s, comprising approximately one third of total arms exports to the Middle East, and future prospects looked even better. Extensive deals had been concluded, two of which were worth more than $f 100$ million (Stahl, 2019).

In addition, arms trade to the Middle East in 1960s could reduce Britain's defense spending. Hence, London could turn the traditional arms assistance to the allies in the Middle East into the more profitable business deal. This aim could be achieved by deploring more British troops in the regions and replaced with the ally's troops. The stationing of British troops in the Middle East, especially the Gulf States, was costly and contributed to the deficit. On July 1966, the British government announced that the military expenses in the Middle East would be cut down with the reduction of the cost approximately $£ 100$ million (Wilson, 1966). 
Eventually, the Labor government announced in 1967 that it was withdrawing its remaining troops from the Arabian Peninsula. This announcement had the effect of not only encouraging small countries like Kuwait to begin building up armies for the first time, but also compelling Iran to order tanks from Britain (Callaghan, 2007). As a consequent, in 1966 one third of all arms exports to developing countries were sent to the Middle East. In fact, arm deals worth more than $f 140$ million had been concluded with Saudi Arabia with the declared purpose of absorbing a portion of the negative effects caused by cuts in defense spending (Phythian, 2000).

Although London had cut down her military expenses in the Middle East by withdrawing her troops from the region, her interest of arms business in the Middle East remains important. Thus, the British government changed her strategy from sending troops into 'selling weapons' to the conflicting nations. Suffice to mention that when the war erupted on Jun 1967, the British government declared her policy to end the war immediately. London emphasized her policy in the UN's debate by Minister of Foreign Affairs dan UK Permanent Representative to the UN, Lord Caradon on 5 July 1967. According to Caradon (1967),

There must be disengagement and withdrawal, there must equally be final security against renewed hostility; there must be relief and rehabilitation on a new and imaginative scale never before contemplated..., there must be demilitarized frontiers, there must be an end of the arms race; there must be a restoration of international authority.

Nonetheless, the policy of the British government to continuously exporting arms supplies to the conflicting nations remain unchanged. As mention earlier, the British policy was very much influenced by a strategy of protecting her business in the region. With the spread of the Soviet threat, any possibility of embargoing the arm sales to the region is considered as a very unwise business decision. A secret memorandum from the British Foreign Office dated 26 Jun 1967 clearly assesened this consideration by indicated that the arm supplies especially to the UAR, Syria, Iraq and Algeria have been a major factor in increasing Russians influence in the Arab world during the last decade (FCO, 1967). Meanwhile, the British Secretary of States for Foreign Affairs, George Brown further admitted this fact by vividly stated;

We have therefore to accept that if we do not sell to Israel and the Arab countries, some other countries (Soviet) will. If we do not continue to supply arms, we should lose not only profitable exports, but any political advantage which our position as supplier might give us (Brown, 1967).

Despite the changes of the UK government from Labor to the Conservative in the 1970's election, the policy of the British government in 1967 war unaltered in the 1973 conflict. Tory government view of securing British economic interests in arms trade at the Middle East still emerged as a high priority in Whitehall foreign policy. When the 1973 war blown up, the immediate action taken by the British during the war was to impose the arms embargo unilaterally towards the confronted countries by immediate effect. The British's government official policy was to seek an immediate ceasefire and a rapid start to meaningful negotiations towards a settlement in accordance with the United Nations (UN) Resolution 242 of 1967. According to the Foreign and Commonwealth Office evaluation that if these objectives failed to be achieved, the situation was bound to deteriorate. Thus, the FCO was afraid that more Arab countries were sucked into the fighting, subsequently posed a risk to the British interests in the Middle East, particularly the oil supplies (Parson,1973). 
The Prime Minister, Sir Edward Heath in 1973 described the embargo as even-handed as he wrote in his autobiography that this was genuinely even-handed approach because, unlike the previous Middle East conflict in 1967, when most of our arms export to the area went to Israel, in 1973 we had been providing arms to the Arab and the Israelis in very similar quantities' (Heath, 1998). Meanwhile in the BBC Program on 12 October, the Foreign Secretary Sir Alec Douglas-Home explained the justification of his government decision regarding the embargo by saying that if you are putting forward a cause of ceasefire, it certainty seems inconsistent to supply either side with arms' (Douglas-Home, 1973). Later in the House of Commons Sir Alex Douglas-Home further elaborated his government policy of the arms embargo. According to Doulas-Home (1973)

We did this (embargo) because we considered it is inconsistent to call for an immediate end to the fighting and yet to continue to send arms to the conflict. This seems to me to be the best posture from which to make an effective contribution to a constructive settlement.

Subsequently by 9 October 1973, the Department of Trade and Industry (DTI) revoked all outstanding export licenses for aircraft, arms military stores and appliances to the Arab countries and Israel (MoD, 1973). Nevertheless, the unilateral embargo by the British government lasted only until 21 January 1974. What was the force of lifting the embargo so soon? From historical analysis, the lifted of the embargo was due to certain possible factors but it was undeniable that the decision was a response to the economic consideration, especially to protect the British arms industry prospect. The pressure to lift the embargo came mostly from the arms supplier firms as well as the government departments which were responsible to the arm supplies industry. For example, based on a minute from the Head of Defense Sales dated 24 October 1973 to the Secretary of Defense, Lord Carrington he argued that the embargo will tarnish the British reputation and reliability as a supplier of defense equipment (HoD, 1973). On separate occasion, the Minister of Defense, lan Gilmour had sent a letter to the Minister of State for Foreign Affairs, Lord Balniel on 8 November 1973 stated that the embargo presented many problems that, unless it is modified soon, there could be $a$ serious loss of business for the United Kingdom, with an adverse effect on a balance of payments and employment (Gilmour, 1973). A further warning addressed again by the Head of Defense Sales to the Secretary of State for Defense on 28 November 1973 to persuade the government of lifting the embargo due to a possibility of losing lucrative contracts from the Arab nations (HoD, 1973).

Critics and pressures also came from the British private firms which have contract deals to supply arms to the Middle Eastern countries. For these private firms, the embargo by the government was not only jeopardizing their existing contracts, but also their reputation as reliable arms suppliers to the Middle East. One of these firms was Marconi Space and Defense System Limited which their scheduled arms delivery to Libya. In a letter by its director R.C Ashworth to the Controller of the Department of Trade and Industry, he wrote that the delay and uncertainty (of delivering the arm equipment to Libya) could seriously affect their whole business in the area (Ashworth, 1973). Another company was Plessey Company Limited whose contract to supply arms equipment to Egypt. In the meeting with officials from the DTI on 20 December, the company representator, Mr. Neville L. Lupton listed the orders worth thousands of pound affected by the embargo and expressed their worry that the inability of delivering the orders could prejudice the company's prospect of securing orders of civil equipment from the Arab countries, particularly in their pursuit of securing a contract for Cairo airport communications equipment worth more than $f 2.5$ million (FCO,1973). 
Consequently, based on all the pressures from various parties, the government agreed to lift the temporary ban by mid of January 1974 .

\section{Conclusion}

In conclusion, there are a few major findings from the above discussion. Firstly, despite the changes of government in London from Labor to Conservative in 1970, the British attitude towards the Arab-Israel Wars in 1967 and 1973 was similar if not identical. The similarity was in the context of safeguarding British economic interests in the region. One of the most important business at that time was the arms trade supply. A second finding from the analysis proven that with the escalation of the conflict, the demands for more arms and ammunitions increased dramatically. Therefore, London stuck in the dilemma between promoting a peace and stability in the region with their intention to increase the arm sales. The former stand was very vital since a stability of the region was very important to ensure the oil flow from the Middle East undisrupted. European countries and Britain traditionally depending on the oil supply from the Arab nations and Iran since decades. Thus, a continuous conflict and wars will jeopardize the oil flow to the West.

Nonetheless, the third important finding of this study is the British lifted the arms embargo in the Arab-Israeli wars because London realized that to continue banning the arm supplies for peace means to lose a lucrative and profitable arm business in the Middle East. The region has emerged as one of the most important market to the British's arms export especially the exports to developing nations. From 1950s to 1970s, the Middle East countries emerged as one of the biggest arm purchasers from Britain. Additionally, with a decision by London to cut down her oversea military expenses by withdrawal troops stationed in the Middle East, a huge requisition of military and defense equipment from the moderate Arab country increased. The withdrawal of British's troop from the Middle East region in 1960s required Britain to well equip her Arab allies with modern military defend equipment. This is urgently important in order to face a spread of subversive activities by the nationalist groups and the insurgency of communist threat which mushrooming under the Soviet's patron. The moderate Arab countries like Jordan, Kuwait and the Gulf Sheikhdoms were strategically very important to the British influences and interests in the region. Without British assistance and protection, the pro-British regimes in these countries may collapse and fall under the revolutionary Arab nations like UAR and Iraq, subsequently surrender to the Soviet's sphere.

In the 1960s and 1970s era, the Soviet threat to the British interests in the Middle East was fiercely and aggressively. Kremlin was very active in sponsoring revolutionary Arab regimes such as President Nasser of the UAR. Concurrently, Soviet and her Communist allies also appeared as a rival to the British arm business deals in the region. Many Arab countries started to purchase military equipment from the Soviet as Kremlin was not being perceived as the Israelis close patron. Hence, if London refuse to sell military appliances to the Arab countries due to the wars, she will not just be losing the lucrative arm deals, but she would be remarked as the unreliable business supplier. Worsen, the British might be viewed as the Israelis supporter and the enemy of the Arab nations. In this dilemma, the British government was diplomatically very wise in balancing her policy approaches between preserving peace and stability in the region with a strategy of protecting a generous arms deal.

From historical comparative perspective,. this study concluded a vital finding that the unchanged policy of the British government between 1967's war and 1973's Arab Israeli War was very much shaped by the arm trades consideration. Despite critics from various parties on her foreign affairs policy, yet with a dramatic political regime substitution in London, the 
British government remained consistent in her diplomatic approaches. Conclusively, the ultimate aim of the British government policy in these wars changeless which was to preserve her fundamental economic interests, especially to protect the arms trade transactions.

From the above conclusion, this study proposes some practical considerations to be appraised in the future especially in any collective efforts by the international community to orchestrate a peace process plan in the Middle East. One of the important aspects is to give more attention on the issue of arms limitation and military balance in the region. It is crucial to ensure that no arms to be supplied to the identified 'aggressor' countries. The suppliers such as from Britain is ethically responsible to investigate the motive of the purchasers to buy the arms. They must scrutinize the purpose of the deal to avoid any possibility of terrorism and aggressor's element like a nation who is sponsoring subversive activities, or any misappropriate affairs by building a nuclear or weapon of mass destruction (WMD).

Subsequently, the arms trade in the Middle East must be monitored closely by the international agencies such as the United Nations Office for Disarmament Affair (UNODA) and the International Atomic Energy Agency (IAEA). The arms exported countries like the United States, Britain, France, European Union (EU) and Russia must be excluded in the monitoring body. The reason is to avoid any conflict of interest in the observation procedure. Ultimately, the arms shall only be exported based on the security reasons such as for national defense or in the purpose of creating peace and stability only. The peacefulness of the region is very important to create a conducive economic environment for trades activities especially the flow of oil for a global market. The traders must remember that money is not everything, but a lasting peace and stability of the region is more crucial to be achieved. As stated by Albert Einstein that "peace cannot be kept by force. It can only be achieved by understanding."

\section{References}

ACDA - US Arms Control and Disarming Agency. (1976). World Military Expenditure and Arm Transfers, 1966-1975. Washington: Government Printing Office.

Ashworth, R.C. (1973). [A letter from R.C Ashworth to the Controller, DTI]. In file FCO 93/292. London: The National Archive.

Brown, G. (1967). [ A Memorandum by the Secretary of State for Foreign Affairs, Arab Attitude and British Economic Interest in the Middle East]. In file FCO 17/34. London: The National Archive.

Brown, G. (1967) [ A note by the Foreign and Commonwealth Secretary, 'Policy for the sale of arms to Israel and the Arab countries]. In file FCO 10/143. London: The National Archive.

Brown, G. (1967). Note by Secretary of State for Foreign and Commonwealth Affairs, Policy for the Arms to Israel and Arab Countries]. In file FCO 17/114. London: The National Archive.

Brown, G. A. (1967). [A note by Secretary of Foreign Affairs, George Brown, 1967]. In file FCO17/114. London: The National Archive.

Brzoska, M., \& Ohlson, T. (1987). Arms Transfer to The Third World. Oxford: Oxford University Press.

Callaghan, J. (2007). The Labor Party and Foreign Policy: A History. Routledge: London.

Caradon, H. M. F. L. (1967) Minute of UN Meeting, no. 1553, 14 July 1967. New York: United Nations.

Croswait, T. L. (1986). [A Report on Arms Sales to Middle East]. In file FCO17/114. London: The National Archive. 
Deger, S. (1986). Military Expenditure in Third World Countries. London: Routledge \& Kegan Paul.

Douglas-Home, A. (1973, 16 October). [Extract from House of Commons, Hansard, Col. 30-41, Vol. 861, 16 October 1973]. In file FCO 93/205. London: The National Archive.

FCO, Foreign and Commonwealth Office. (1973). [Extraction from the interview of the BBC Programme TODAY on 12 October 1973, telegram no. 528]. In file FCO 93/262. London: The National Archive.

FCO, Foreign and Commonwealth Office. (1973). [A Minute of Meeting between Plessey's representatives and the DTI]. In file FCO 93/565. London: The National Archive.

FCO, Foreign and Commonwealth Office. (1967). [Guidance no 160, Memorandum from The FCO to British missions oversea]. In File FCO 12/112. London: The National Archive.

Gilmour, I. (1973). [A Letter from Ian Gilmour to Lord Balniel].In file DEFE 13/942. London: The National Archive.

Gottheil, F. (1974). An Economic Assessment of the Military Burden in the Middle East 19601980. Journal of Conflict Resolution, 18 (3), 502-503.

Heath, E. (1998). The Autobiography of Edward Heath: The Course of My Life. London: Hodder \& Stoughton.

HoD, Foreign and Commonwealth Office. (1973). [A minute from Head of Defence Sales to Secretary of Defence]. In file DEFE 13/942. London: The National Archive.

HoD, Ministry of Defence. (1973). [Extract from Ministry of Defense's memo, a minute by Head of Defense Sales to Private Secretary of the Secretary of State for Defense] In file DEFE 13/1492. London: The National Archive.

MoD, Ministry of Defence. (1973). [A Report by MoD] In file DEFE 13/942. London: The National Archive.

MoD, Ministry of Defence, UK. (1967). [Record of British Sales of Defence Equipment], In file PREM 15/296. London: The National Archive.

Parson, A. D. (1973). [A Minute from A.D Parsons, Under Secretary of State to Mr. Alexander, Blackpool]. In file FCO 93/205. London: The National Archive.

Phythian, M. (2000). The Politics of British Arm Sales Since 1964. Manchester: Manchester University Press.

Stahl, D. (2019). The Decolonization of the Arms Trade: Britain and the Regulation of Exports to the Middle East. History of Global Arms Transfer, (7), 14- 15.

Wilson, H. (1966). Parliamentary Hansard. Vol. 732, Cols. 623-633. London: House of Commons. 